doi:10.4149/neo_2013_081

\title{
Proteasome inhibition leads to altered signaling in the proteome of cisplatin-resistant human ovarian carcinoma cell line
}

\author{
J. DURAJ, M. PASTOREK, J. VITKOVSKA, D. CHOLUJOVA, P. GRONESOVA, L. HUNAKOVA, J. SEDLAK \\ Cancer Research Institute, Slovak Academy of Sciences, Vlarska 7, 833 91, Bratislava, Slovakia \\ *Correspondence: jozef.duraj@savba.sk
}

Received December 17, 2012 / Accepted July 8, 2013

\begin{abstract}
To address a precise view into molecular mechanisms of apoptotic signaling pathways after single- or combinatory treatments with specific NF- $\kappa \mathrm{B}$ - or proteasome inhibitors and/or cisplatin (CDDP), flow cytometry and western blotting of the cell proteome in human ovarian chemosensitive- and CDDP-resistant cell lines were used. We report here that proteasome inhibition (but not NF- $\kappa \mathrm{B}$ inhibition) caused marked alterations in the cell proliferation and cell cycle, as well as in the levels of signaling anti- and pro-apoptotic proteins PARP, NF- $\kappa \mathrm{B}, \mathrm{I} \kappa \mathrm{B}-\alpha, \mathrm{Bcl}-2$, Bax, and lysosome-associated LAMP-1 and ATP-7B molecules in particular proteome fractions. These findings refer to the possibility of regulation of CDDP resistance, inclusive the capacity of lysosomes to export CDDP in certain human ovarian cancer cells by proteasome inhibition.
\end{abstract}

Key words: cisplatin resistance, cell proteome, NF- $\kappa B$ - and proteosome inhibition, flow cytometry, western blotting

The development of CDDP resistance in diverse human cancer cells, inclusive ovarian cancer, often contributes to the therapeutic failure. Accumulating evidence suggests that anticancer drugs, inclusive CDDP, activate the nuclear transcription factor kappa B (NF- $\mathrm{BB})$, a proinflammatory factor that has emerged as an important player in the development and progression of malignant cancers $[1,2]$. NF- $\kappa B$ targets genes that promote tumor cell proliferation, survival, metastasis, inflammation, invasion, apoptosis and angiogenesis [3] and is relevant in the final response of normal and cancer cells to platinum drugs $[4,5]$. Furthermore, NF- $\kappa B$ inhibition of activation and translocation sensitizes cancer cells to the effects of several anticancer compounds $[6,7]$. Thus, combination of conventional chemotherapeutics with NF- $\mathrm{KB}$ inhibitors has been considered as an adjunct approach to sensitize cancer cells to chemotherapy $[8,9]$.

The ubiquitin proteasome pathway represents the major catabolic pathway for intracellular protein degradation of short-lived and misfolded proteins including those involved in the cell cycle, apoptosis, transcription, DNA repair, protein quality control and antigen presentation [10]. Importantly, defects within this pathway are associated with a number of diseases, including cancer $[11,12]$. At present accumulating evidence suggests that targeting the ubiquitin proteasome pathway by proteasome inhibitors leads to the inhibition of cell proliferation, alters the pathways leading to the NF- $\mathrm{BB}$ activation and subsequent translocation of this transcription factor to the nucleus to activate downstream pathways responsible for sensitization cancer cells to several anticancer agents $[13,14]$.

Several dozens of proteins including pro- and antiapoptotic members of the $\mathrm{Bcl}-2$ protein family have been shown to modulate the response to CDDP. Elevated levels of their antiapoptotic counterparts, including $\mathrm{Bcl}-2, \mathrm{Bcl}-\mathrm{xl}$ and $\mathrm{Mcl}-$ 1 (myeloid cell leukemia sequence 1), correlate with CDDP resistance in different clinical scenarios, including head and neck cancer, ovarian cancer and NSCLC $[15,16]$.

A great deal of attention was devoted to the two copper extruding P-type ATPases, ATP-7A and ATP-7B, as well as to the associated LAMP-1 and LAMP-2 proteins appeared to be upregulated in CDDP-resistant cancer cells [17, 18]. Notably, clinical studies indicate that ATP-7B expression levels might predict the sensitivity of ovarian and endometrial cancers to CDDP chemotherapy $[19,20]$.

The aim of this study was in human ovarian carcinoma parental cells A2780 and their chemoresistant counterparts A2780/CP to examine cellular proteome responses after cell treatments with specific NF- $\mathrm{kB}$ - or proteasome inhibitors and 
in their individual combination with anticancer agent CDDP, respectively. We here report that in comparison with NF- $\kappa B$ inhibition, merely proteasome inhibition, or its combination with CDDP, correlated with effective inhibition of CDDP-resistance resulting in marked alterations in signaling/apoptotic survival pathways associated with exosomal pathways that participitate in CDDP export.

\section{Materials and methods}

Reagents. Propidium iodide (PI) and cisplatin (CDDP) were products of Sigma-Aldrich (St. Louis, MO, USA). NF$\kappa \mathrm{B}$ activating inhibitor (NF- $\kappa \mathrm{B}-\mathrm{AI})$ and proteasome inhibitor I (PSI-I) were purchased from Calbiochem (San Diego, CA, USA). Fluoresceindiacetate (FDA) was a product of Molecular Probes (Eugene, Oregon, USA). Polyclonal antibodies against PARP, ATP-7B, mouse monoclonal antibody against LAMP-1, secondary HRP-IgGs and chemiluminiscence reagent (ECL) were purchased from Santa Cruz Biotechnology, Inc. (CA, USA). Polyclonal Bax, Bcl-2, Bcl-xL, NF- $\kappa B$ and IкB- $\alpha$ antibodies were obtained from Cell Signaling Technology, Inc. (MA, USA).

Cells and cytotoxicity assay. Human ovarian carcinoma cell line A2780 and its CDDP-resistant subline A2780/CP were obtained from ECACC (No. 93112519 and 93112517 , respectively) and routinely cultured in RPMI 1640 medium supplemented with $10 \%$ heat-inactivated FCS, $2 \mathrm{mM}$ L-glutamine, $100 \mu \mathrm{g} / \mathrm{ml}$ penicillin and $50 \mu \mathrm{g} / \mathrm{ml}$ streptomycin, in $5 \% \mathrm{CO}_{2}$ humidified atmosphere, at $37^{\circ} \mathrm{C}$. For the experiments, approximately $0.5 \times 10^{6}$ cells $/ \mathrm{ml}$ were cultivated individually with NF- $\mathrm{KB}$-AI or PSI-I, and/or CDDP, with indicated doses (inhibitors were selectively added 3 hours prior to CDDP administration) in 96, 12 or 6 well plates (Greiner, Germany). Cytotoxicity of triplicates was measured after 48 hours and cell survival was determined by MTT assay [21]. Briefly, cells were plated at 1-2 x $10^{3}$ cell density in 96-well culture plates, incubated with $50 \mu \mathrm{l}$ of MTT $(1 \mathrm{mg} / \mathrm{ml})$ and left in the dark at $37^{\circ} \mathrm{C}$ for an additional 4 hours. Finally, culture medium was removed, formazan crystals were dissolved in DMSO $(200 \mu \mathrm{l})$ and the absorbance was measured at $540 \mathrm{~nm}$ and $690 \mathrm{~nm}$ in Microplate reader (Dynatech Lab Inc., Chantilly, VA, USA). The IC50 and combination indices $\left(\mathrm{CI}^{*}\right)$ were determined by Calcusyn software (version 1.1, Biosoft).

Cell cycle analysis. Cell cycle determination was based on the cytometric measurements of the DNA content in nuclei labeled with propidium iodide (PI). Untreated or treated cells were kept in PBS containing $0.05 \%$ Triton X100 and $15 \mu \mathrm{l}$ RNA-se $\mathrm{A}(10 \mathrm{mg} / \mathrm{ml})$ at $37^{\circ} \mathrm{C}$, for $20 \mathrm{~min}$. Further, the cells were cooled and incubated on ice for 10 minutes and then PI $(50 \mu \mathrm{g} / \mathrm{ml})$ was added. Finally, the stained cells were analyzed using Beckman FACS Canto II flow cytometer [22]. Cell cycle was analysed with MultiCycle AV Plug-in to FCS Express version 3 software, Los Angeles, CA, USA.
Flow cytometric analysis of apoptosis. Apoptotic cell enumeration was evaluated by the amount of cells with the cell membrane impermeable for PI and decreased amount of fluorescein [23]. Approximately $5 \times 10^{5}$ untreated or treated cells were resuspended in $400 \mu \mathrm{l}$ of $\mathrm{PBS} / 0.2 \%$ BSA containing $10 \mathrm{nM}$ of FDA at room temperature, for $30 \mathrm{~min}$. Then the cells were cooled, incubated with $4 \mu \mathrm{l}$ of PI $(1 \mathrm{mg} / \mathrm{ml})$ for 15 min on ice and measured using Beckman FACS Canto II flow cytometer. Data were analysed with FCS Express version 3, De Novo Software, Los Angeles, CA, USA.

Cell proteome fractions and western blot analysis. To study subcellular proteomes we used fast and reproducible extraction executed by the ProteoExtract ${ }^{\oplus}$ Subcellular Proteome Extraction Kit (S-PEK, Calbiochem, USA). Cultured cells $\left(5 \times 10^{6}\right)$ were washed in PBS and lysed in S-PEK buffered lysis system containing phosphatase inhibitors ( $2 \mathrm{mM}$ sodium orthovanadate, $2 \mathrm{mM}$ sodium fluoride) and then we worked according to the procedure recommended by the provider. Equal portions of protein lysates (10 $\mu \mathrm{l}$ for each of $\mathrm{F} 1$ - F4 fractions) were run in $12.5 \%$ SDS/PAGE gels, transferred to nitrocellulose membrane and incubated with corresponding polyclonal/monoclonal IgGs. The protein-antibody complexes were detected using secondary HRP-IgGs followed by enhanced chemiluminescence reagent (ECL).

\section{Results}

MTT assay and combination indices $\left(\mathrm{CI}^{*}\right)$. In all experiments the two inhibitors were used: NF- $\kappa B$ specific activation inhibitor, NF- $\mathrm{kB}-\mathrm{AI}$ (a highly potent inhibitor of $\mathrm{NF}-\kappa \mathrm{B}$ transcriptional activation) and proteasome inhibitor I, PSI-I (reversible proteasome inhibitor with chymotrypsinlike activity of the multicatalytic proteinase complex of $20 \mathrm{~S}$ proteasome). To assess the effects of NF- $\mathrm{KB}-\mathrm{AI}$, PSI-I, and/or CDDP, chemosensitive (A2780) and CDDP-resistant (A2780/CP) human ovarian cancer cells were processed with the drugs in dose dependent manner (Fig. 1). Unexpectedly, $0.1-5 \mu \mathrm{M}$ and even higher (> $5 \mu \mathrm{M}$, data not shown) doses of NF- $\mathrm{kB}$-AI had minimal effect on the viability of both cell variants. By contrast, nanomolar concentrations of PSI-I exerted effective inhibition of cell proliferation of the studied cell sublines. Calculating from MTT assay and $\mathrm{CI}^{\star}$ (Tab. 1), drug concentrations for further experiments were fixed at $0.5 \mu \mathrm{M}$ (NF- $\kappa \mathrm{B}-\mathrm{AI})$ or $20 \mathrm{nM}$ (PSI-I) for both cell variants, and $10 \mu \mathrm{M}$ CDDP for sensitive-, and $25 \mu \mathrm{M}$ CDDP for resistant cells, respectively. The obtained results showed that administration of NF- $\mathrm{KB}-\mathrm{AI}$ rendered only slight effect on CDDP activity $\left(\mathrm{CI}^{*} \sim 1\right)$ in the studied cell variants, while co-treatment with PSI-I and CDDP induced synergistic effect $\left(\mathrm{CI}^{*}<1\right)$ in these sublines.

Flow cytometry of the cell cycle and apoptosis. In both cell variants, long-term (48 hours) treatments with NF-kB-AI or PS-I and/or CDDP induced diverse cell cycle alterations. Single CDDP induced predominantly S-phase 
arrest in these cells. Unexpectedly, single NF- $\mathrm{kB}$-AI had no effect on the cell cycle course of the studied cells, whereas PS-I administration accumulated both cell subtypes in $\mathrm{S}$ and G2/M cell cycle phases. Of interest, while NF- $\kappa B-$ AI exerted no significant effect on the cell cycle of CDDP treated cells, co-treatment with PS-I and CDDP partially reduced the cell number in $S$ phase with increased G2/M phase (Fig. 2 A).

To evaluate apoptotic events due to drug treatments, FDA/ PI staining and cytometric measurements were executed. Fig. $2 \mathrm{~B}$ depicts the percentage of viable (FDA+/PI-, V), apoptotic (FDA-/PI-; A) and necrotic (FDA-/PI+; N) cells exposed to 48 hour drug treatments. The obtained results demonstrate that single NF- $\mathrm{kB}-\mathrm{AI}$, or in combination with CDDP, exerted no substantial effect on the viability of both cell sublines and apoptotic cell portions corresponded in parental cells merely to CDDP effect. In contrast, proteasome inhibition with PSII led to increased percentage of apoptotic cells in both cell variants and this was significantly potentiated by the co-treatment with CDDP.

Western blot analysis of subcellular proteomes. ProteoExtract ${ }^{\circledR}$ Subcellular Proteome Extraction Kit (S-PEK) was designed for fast and reproducible extraction of subcellular proteomes from adherent and suspension-grown mammalian cells. S-PEK takes advantage of the different solubilities of certain subcellular compartments in the four selected reagents. The stepwise extraction thus delivers four distinct protein frac-

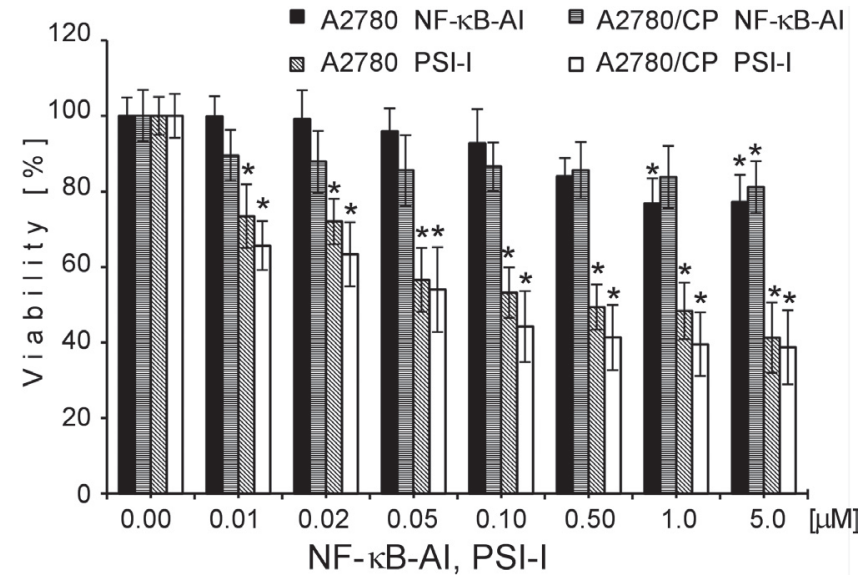

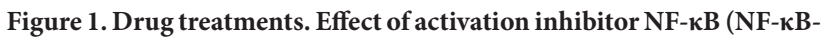
AI), proteasome inhibitor I (PSI-I) or their combination with CDDP on viability of human parental (A2780)- and CDDP-resistant (A2780/CP) ovarian carcinoma cells treated for $\mathbf{4 8}$ hours with appropriate inhibitors at the indicated concentrations are shown. Data represent means of the three independent experiments. Statistical significance from the controls was inferred at ${ }^{*} \mathbf{p}<0.05$.

tions from one sample: cytosolic- (F1), membrane/organelle protein- (F2), nuclear protein- (F3), and cytoskeletal fraction (F4), allowing to determine possible quantitative alterations in protein signaling molecules and their distribution during

Table 1. Combination index values $\left(\mathrm{CI}^{*}\right)$. MTT assays of parental (A2780)- and CDDP-resistant (A2780/CP) cells after 48 hour exposition to 0.01 - 5 $\mu \mathrm{M}$ NF-kB-AI or PSI-I were calculated. Both inhibitors were administered to the cell cultures three hours before CDDP, and then corresponding 2.5, 5 or $10 \mu \mathrm{M}$ concentrations of CDDP (for sensitive cells), or 5, 10 or $25 \mu \mathrm{M}$ (for chemoresistant cells) were added. The data with the means (+/- SD) of the three independent experiments are shown.

\begin{tabular}{|c|c|c|c|c|c|c|}
\hline \multirow[b]{3}{*}{$(\mu \mathrm{M})$} & \multicolumn{3}{|c|}{ A2780 } & \multicolumn{3}{|c|}{$\mathrm{A} 2780 / \mathrm{CP}$} \\
\hline & \multicolumn{6}{|c|}{ CDDP } \\
\hline & 2,5 & 5 & 10 & 5 & 10 & 25 \\
\hline NF-kB-AI & \multicolumn{6}{|c|}{$\mathrm{CI}^{*}$} \\
\hline 0,01 & $0.98+/-0.03$ & $0.96+/-0.01$ & $0.91+/-0.02$ & $0.98+/-0.06$ & $0.97+/-0.04$ & $0.94+/-0.06$ \\
\hline 0,02 & $0.99+/-0.13$ & $0.97+/-0.02$ & $0.88+/-0.03$ & $0.99+/-0.04$ & $1.15+/-0.05$ & $1.08+/-0.08$ \\
\hline 0,05 & $0.86+/-0.05$ & $0.94+/-0.02$ & $0.93+/-0.05$ & $0.87+/-0.07$ & $0.98+/-0.05$ & $1.05+/-0.03$ \\
\hline 0,1 & $1.15+/-0.05$ & $1.26+/-0.06$ & $0.87+/-0.06$ & $1.03+/-0.09$ & $0.81+/-0.06$ & $1.10+/-0.10$ \\
\hline 0,5 & $1.05+/-0.07$ & $1.17+/-0.13$ & $0.98+/-0.03$ & $1.07+/-0.11$ & $0.93+/-0.04$ & $1.19+/-0.15$ \\
\hline 1 & $0.94+/-0.01$ & $0.95+/-0.12$ & $0.92+/-0.03$ & $1.02+/-0.15$ & $0.99+/-0.07$ & $1.08+/-0.10$ \\
\hline 5 & $0.96+/-0.06$ & $1.20+/-0.10$ & $1.01+/-0.01$ & $1.11+/-0.09$ & $1.22+/-0.17$ & $1.18+/-0.20$ \\
\hline PSI-I & \multicolumn{6}{|c|}{$\mathrm{CI}^{*}$} \\
\hline 0,01 & $0.70+/-0.06$ & $0.64+/-0.14$ & $0.71+/-0.08$ & $0.67+/-0.05$ & $0.64+/-0.04$ & $0.60+/-0.06$ \\
\hline 0,02 & $0.73+/-0.11$ & $0.59+/-0.11$ & $0.62+/-0.08$ & $0.63+/-0.05$ & $0.58+/-0.06$ & $0.54+/-0.14$ \\
\hline 0,05 & $0.84+/-0.07$ & $0.86+/-0.10$ & $1.00+/-0.10$ & $0.80+/-0.10$ & $0.85+/-0.07$ & $0.77+/-0.08$ \\
\hline 0,1 & $0.84+/-0.04$ & $1.06+/-0.06$ & $0.83+/-0.11$ & $0.83+/-0.07$ & $0.88+/-0.08$ & $0.78+/-0.07$ \\
\hline 0,5 & $0.83+/-0.07$ & $0.88+/-0.09$ & $0.90+/-0.08$ & $0.82+/-0.08$ & $0.89+/-0.09$ & $0.79+/-0.07$ \\
\hline 1 & $1.18+/-0.28$ & $0.92+/-0.16$ & $0.94+/-0.24$ & $0.87+/-0.08$ & $0.94+/-0.18$ & $0.90+/-0.18$ \\
\hline 5 & $1.14+/-0.24$ & $1.28+/-0.52$ & $0.96+/-0.12$ & $1.15+/-0.20$ & $1.21+/-0.17$ & $1.10+/-0.22$ \\
\hline
\end{tabular}




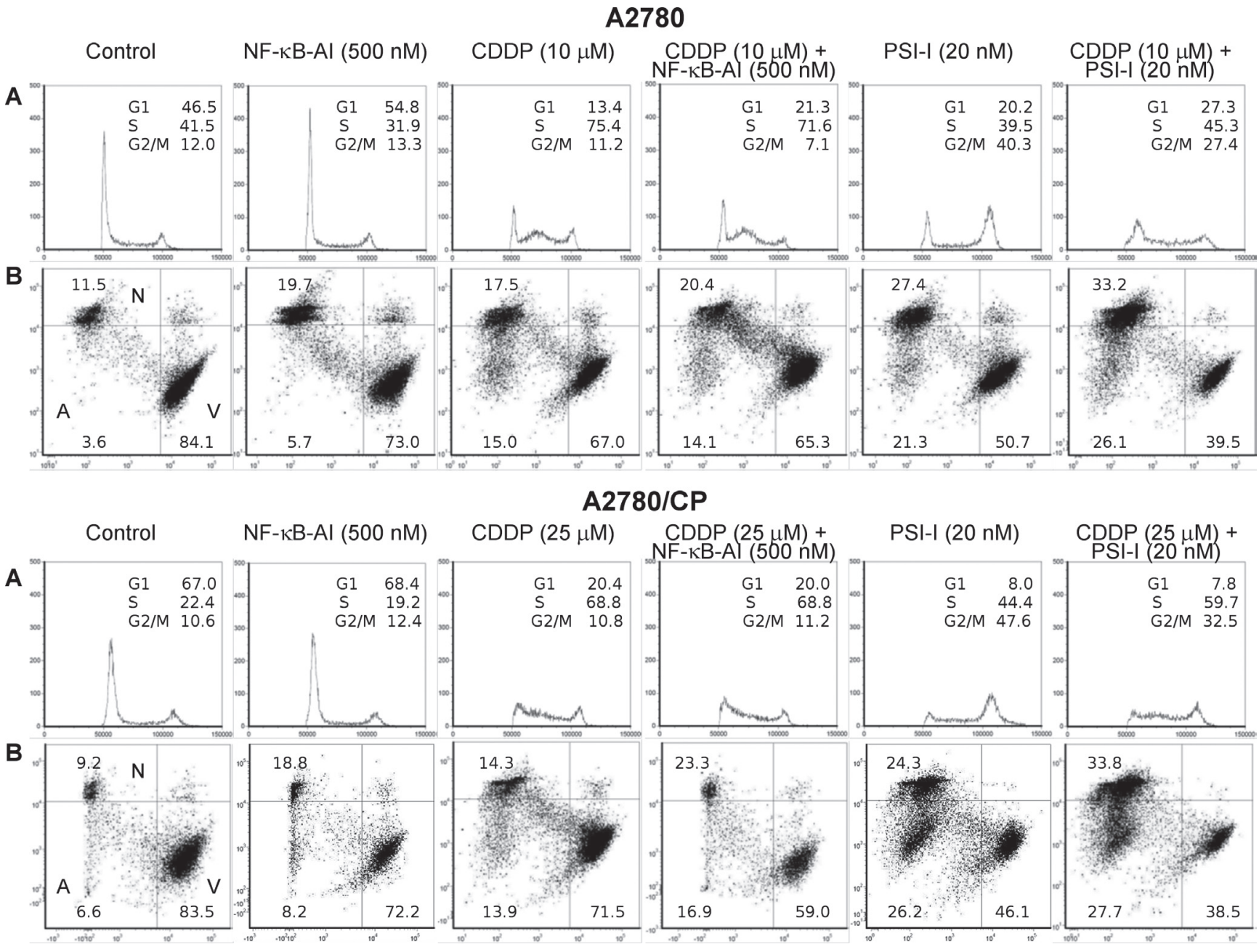

Figure 2. Flow cytometry measurements. Analysis of ovarian parental (A2780)- and CDDP-resistant (A278/CP) cells: A - propidium iodide (PI) permeabilized cells (cell cycle/DNA analysis; percentage of cells in G1, S, G2/M phase); B - fluorescein diacetate (FDA) stained cells; V - cells in the cell cycle (FDA+/PI-), A - apoptotic cells (FDA-/PI-), N - necrotic cells (FDA-/PI+); Control - untreated cells. Approximately $5 \times 10^{5}$ cells of both cell sublines were processed with NF- $\mathrm{kB}-\mathrm{AI}(0.5 \mu \mathrm{M})$, or PSI-I ( $20 \mathrm{nM}$ ), and/or $10 \mu \mathrm{M}$ CDDP (for parental cells), and/or $25 \mu \mathrm{M}$ CDDP (for resistant cells), for 48 hours. The data show a representative of the two independent experiments.

the processes such as cell differentiation or drug resistance regulation.

To gain a deeper insight into molecular mechanism(s) of a complex intracellular apoptosis signaling network that ultimately regulates gene expression in response to NF- $\mathrm{kB}-\mathrm{AI}$ or PS-I and/or CDDP, we used western blotting to analyse particular subcellular proteomes (Fig. 3). Of note, after the treatments with NF- $\mathrm{kB}-\mathrm{AI}$ no substantial changes in signaling pro- and anti-apoptotic molecules PARP, NF- $\mathrm{BB}, \mathrm{I}-\kappa \mathrm{Ba}, \mathrm{Bcl}-2$, Bax and lysosomal LAMP- 1 and ATP-7B were determined in both sublines examined. On the other hand, marked alterations in these molecules distributed in proper cell proteome fractions were found after proteasome inhibition with PSII or its combination with CDDP. Apoptotic events induced by PS-I and/or CDDP were indicated in both cell variants as
PARP cleavage in nuclear fraction (prominent in F3), downregulation of NF- $\kappa B$ in nuclear (F3)-, I $\kappa B-\alpha$ in cytosolic (F1)-, and $\mathrm{Bcl}-2$ in membrane/organelle protein fraction (F2), or upregulation of $\mathrm{Bax}(\mathrm{F} 2)$, where the later, in comparison with untreated cells, was almost equally distributed in both F2 and F3 subcellular compartments. Interestingly, NF- $\kappa B$ expression levels (constitutively upregulated in resistant cells) linked to nuclear fraction (F3), due to apoptotic events were markedly reduced in $\mathrm{F} 3$, and this was accompanied by IкB- $\alpha$ downregulation in cytosolic compartment (F1). Furthermore, western blots showed that the membrane/organelle protein fraction (F2) from chemosensitive cells comprised much higher constitutive amounts of lysosomal LAMP-1 and ATP-7B protein levels then those found in chemoresistant counterparts. Notably, apoptotic events induced by PSI-I and/or CDDP correlated 


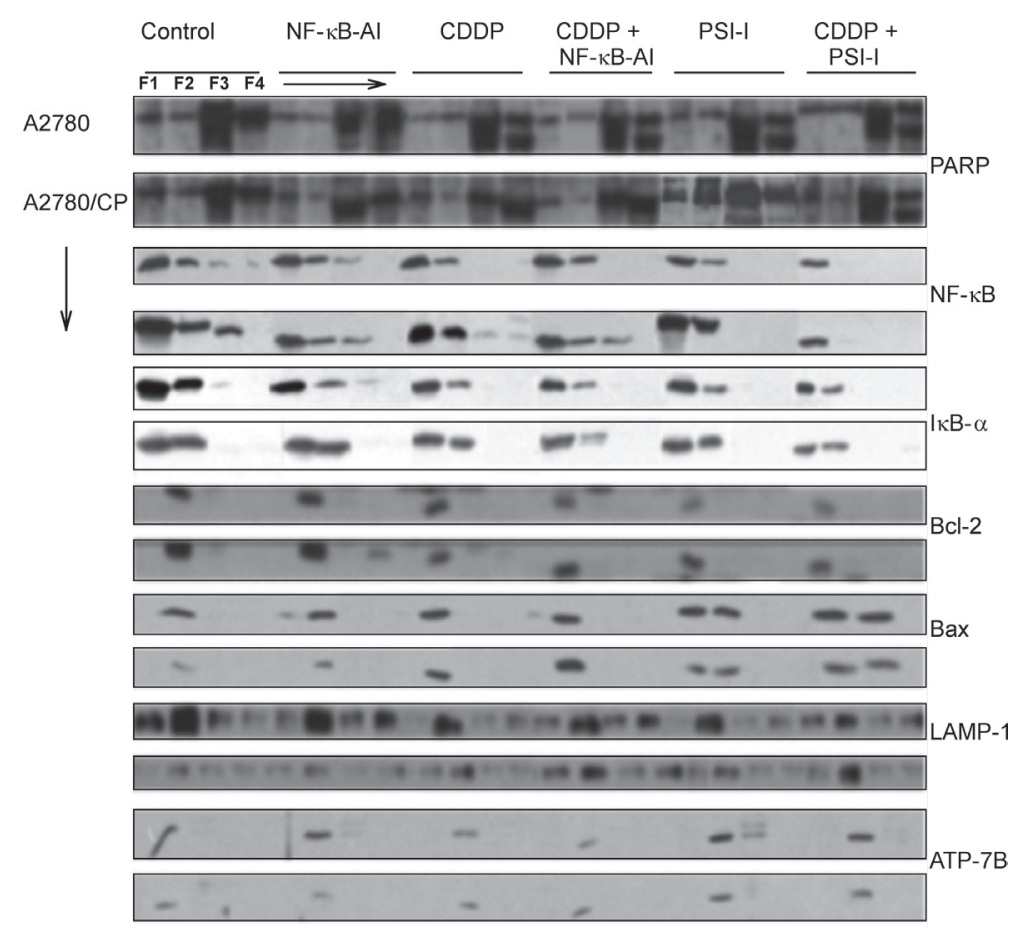

Figure 3. Western blot analysis. Signaling/apoptosis molecules PARP, NF-кB, IкB- $\alpha$, Bcl-2, Bax, LAMP-1 and ATP-7B of cell proteomes (fractions F1 - F4) were detected in ovarian parental (A2780)- and CDDP-resistant (A278/CP) cells with the use of corresponding antibodies. The cells were treated with the drugs as indicated in Fig. 2 and as described in Materials and methods. Control - untreated cells. Representative western blots of the two independent experiments are shown.

in chemoresistant cells with elevated levels of LAMP-1 and ATP-7B molecules.

\section{Discussion}

Several anticancer drugs, including platinum compounds, have been reported to induce NF- $\kappa B$ activation in diverse cancer cells [24-26]. Activation of NF- $\kappa B$ contributes to aggressive tumor growth and also to chemotherapy resistance, and, on the other hand, NF- $\kappa B$ inactivation mediates decreased activity of anti-apoptotic- and increased upregulation of apoptotic genes $[27,28]$. In line with this fact, in recent years much effort has been invested in developing NF- $\kappa B$-blocking agents, including CDDP, natural compounds and their semisynthetic or synthetic analogues [29-31].

The ubiquitin-proteasome pathway plays an important role in NF- $\kappa \mathrm{B}$ regulation of the cell cycle, tumor growth, and metastasis $[32,33]$. Therefore, proteasome inhibitors have been developed to inhibit tumor growth and angiogenesis and their efficacy was vigorously investigated mainly in hematological malignancies [34,35]. Recently, chemosensitizing activity of proteasome inhibitor bortezomib (PS 341) has ben well documented in the treatment of multiple myeloma, and this may be due, at least in part, to the inhibition of NF- $\mathrm{KB}[36,37]$.

In order to find the relationship between NF- $\mathrm{KB}$ transcriptional and proteasomal activity, in relation to combination therapy with CDDP, some events associated with the cell growth, cell cycle and the expression of apoptotic cell portions in chemosensitive- and chemoresistant human ovarian cancer cell lines were evaluated. For this aim we used a cell-permeable highly potent inhibitor of NF- $\kappa \mathrm{B}$ transcriptional activation (NF- $\mathrm{kB}-\mathrm{AI}$ ) and reversible proteasome inhibitor I (PS-I) with chymotrypsin-like activity. Here we provide evidence that, in contrast with NF- $\kappa B$ inhibition, intervention in the proteasome resulted in reduced cell growth, cell cycle arrest and markedly enhanced numbers of apoptotic cells. Moreover, combination treatments executed with PSI-I and CDDP showed synergy to induce apoptotic events not only in parental but also in chemoresistant subline.

To confirm these observations we analyzed for the first time subcellular proteomes obtained with the aid of proteome extraction buffer system. This technique allowed us in four cell fractions to determine distinct protein molecules and study their possible translocation due to alterations in cell signaling/apototic events, as a result of potential CDDP resistance modulation. The experiments revealed that specific NF- $\kappa B-A I$ exerted no substantial efficacy of inhibition CDDP resistance monitored by western blots of the pro- and anti-apoptoticassociated proteins PARP, NF- $\kappa \mathrm{B}, \mathrm{I} \kappa \mathrm{B}-\alpha, \mathrm{Bcl}-2$, and Bax. In contrast to NF- $\mathrm{kB}-\mathrm{AI}$ activity, cell proteome lysates prepared from the cells treated with PSI-I revealed increased portion of apoptotic cells in both cell variants and these were increased 
by combined administration of PS-I and CDDP. These events led to PARP cleavage in nuclear fraction (F3), NF- $\mathrm{KB}$ (constitutively upregulated in resistant cells) decrease in cytosolic (F1)-, membrane/organelle (F2) fractions, as well as in nuclear fraction (F3), accompanied by downregulation of IкB- $\alpha$ in cytosolic fraction (F1). This refers to the fact of blocked NF$\kappa \mathrm{B}$ transport to the nucleus, its accumulation and subsequent degradation in cytoplasm followed by blocked IкB- $\alpha$ transport to proteasome and its intracellular degradation. Apoptotic events also led to both Bcl-2 decrease and enhanced Bax levels in F2. Similar results we obtained by the use of another proteasome inhibitor, naturally occurring triterpenoid pristimerin (data not shown). These observations are in relation with those determined in CDDP-resistant HL60/B cells with higher levels of NF- $\kappa B 50$ and NF- $\kappa B 65$, where the block of IкB degradation by the proteasome inhibitor PS-I induced cell death [38]. Furthermore, in combination with some conventional chemotherapeutics, proteasome inhibitors including PSI-I, lactacystin and bortezomib increased their cytotoxic activity accompanied by the decrease of several anti-apototic molecules or enhanced apoptotic activity in diverse human cancer cells $[39,40]$. Further, accumulating evidence suggests that overexpression of antiapoptotic members of the Bcl-2 protein family, $\mathrm{Bcl}-2, \mathrm{Bcl}-\mathrm{xl}$ and MCL- 1 confers resistance to several stressors in vitro. In this context, ongoing clinical trials are evaluating the combination of CDDP with small molecules that inhibit Bcl-2-like proteins (for example, ABT-263, ABT-737) for the treatment of several neoplasms $[15,16,39]$. On the other hand, it has been referred that deficiency of Bax/Bak-proapoptotic members of the Bcl-2 protein family confers resistance to several compounds inclusive CDDP $[41,42]$.

It was further of particular interest to find if the levels of lysosomal associated protein LAMP- 1 and ATP-7B in the studied cells were modified by NF-KB- or proteasome inhibition. As showed western blots, administered NF- $\mathrm{kB}-\mathrm{AI}$ inhibitor exerted no significant effect upon these protein levels found in membrane-organelle fractions (F2) in both cells sublines. Intriguingly, apoptotic events induced by PSI-I inhibition or its combination with CDDP, led to marked enhancement of these lysosomal molecules in chemoresistant cells that could point to a worsened transport of CDDP out of the resistant cells. The link between CDDP-resistant phenotype and lysosomal/exosomal CDDP export would be based on the fact of the sequestration of CDDP into lysosomes associated with ATP-7A and ATP-7B copper transporters, multidrug resistant protein transporter MRP2 (ABCB2), as well as with LAMP-1 and LAMP-2 proteins [17-20].

The obtained results justify us to assume that inhibiton of NF- $\kappa B$ transcriptional activation, i.e. blocking the interaction between RNA polymerase and a particular DNA promoter may not be sufficient to modulate/reverse CDDP resistance in studied ovarian CDDP-resistant cells monitored by the appearance of apoptosis. By contrast, proteasome inhibition, at least that exerted by the chymotrypsin-like activity of the multicatalytic proteinase complex of $20 \mathrm{~S}$ proteasome, ap- peared as effective to stimulate apoptotic pathways which were potentiated by CDDP. Therefore, the relevancy of the expression status, transcriptional activity and nuclear translocation of NF- $\mathrm{kB}$ upon apoptosis needs to be carefully interpreted in diverse experimental cell systems. Thus, here presentend results indicate the possibility to circumvent CDDP resistance by proteasome inhibition and the capacity of combination therapy with specific proteasomal inhibitors and chemotherapeuticals that might be exploited for reverting CDDP resistance in human tumors.

Acknowledgements: This work was supported by VEGA projects 2/0183/10 and 2/0177/11, Slovakia. The excellent technical cooperation of Mrs. M. Sulikova si greatly appreciated.

\section{References}

[1] OLIVIER S, ROBE P, BOURS V. Can NF-kappaB be a target for novel and efficient anti-cancer agents? Biochem Pharmacol 2006; 72: 1054-1068. http://dx.doi.org/10.1016/ j.bcp.2006.07.023

[2] SARKAR FH, LI Y, WANG Z, KONG D. NF-kappaB signaling pathway and its therapeutic implications in human diseases: Int Rev Immunol 2008; 27: 293-319. http://dx.doi. org/10.1080/08830180802276179

[3] SETHI G, SUNG B, AGGARWAL BB. Nuclear factor-kappaB activation: from bench to bedside. Exp Biol Med 2008; 233: 21-31. http://dx.doi.org/10.3181/0707-MR-196

[4] CHUANG SE, YEH PY, LU YS, LAI GM, LIAO CM, et al. Basal levels and patterns of anticancer drug-induced activation of nuclear factor-kappaB (NF-kappaB), and its attenuation by tamoxifen, dexamethasone, and curcumin in carcinoma cells. Biochem Pharmacol 2002; 63: 1709-1716. http://dx.doi. org/10.1016/S0006-2952(02)00931-0

[5] FRANCESCATO HD, COSTA RS, SCAVONE C, COIMBRA TM. Parthenolide reduces cisplatin-induced renal damage. Toxicology 2007; 230: 64-75. http://dx.doi.org/10.1016/ j.tox.2006.10.025

[6] MABUCHI S, OHMICHI M, NISHIO Y, HAYASAKA T, KIMURA A, et al. Inhibition of NFkappaB increases the efficacy of cisplatin in in vitro and in vivo ovarian cancer models. J Biol Chem 2004; 279: 23477-23485. http://dx.doi. org/10.1074/jbc.M313709200

[7] RUAN HY, MASUDA M, ITO A, UMEZAWA K, NAKASHIMA T, et al. Effects of a novel NF-kappaB inhibitor, dehydroxymethylepoxyquinomicin (DHMEQ), on growth, apoptosis, gene expression, and chemosensitivity in head and neck squamous cell carcinoma cell lines. Head Neck 2006; 28: 158-165. http://dx.doi.org/10.1002/hed.20304

[8] MLYNARCZUK-BIALY I, ROECKMANN H, KUCKELKORN U, SCHMIDT B, UMBREEN S, et al. Combined effect of proteasome and calpain inhibition on cisplatin-resistant human melanoma cells. Cancer Res 2006; 66: 7598-7605. http://dx.doi.org/10.1158/0008-5472.CAN-05-2614

[9] VENKATRAMAN M, ANTO RJ, NAIR A, VARGHESE M, KARUNAGARAN D. Biological and chemical inhibitors of 
NF-kappaB sensitize SiHa cells to cisplatin-induced apoptosis. Mol Carcinog 2005; 44: 51-59. http://dx.doi.org/10.1002/ $\underline{\text { mc. } 20116}$

[10] ADAMS J. The development of proteasome inhibitors as anticancer drugs. Cancer Cell 2004; 5: 417-421. http://dx.doi. org/10.1016/S1535-6108(04)00120-5

[11] NAUJOKAT C, HOFFMANN S. Role and function of the $26 \mathrm{~S}$ proteasome in proliferation and apoptosis. Lab Invest 2002; 82: 965-980.

[12] MEINERS S, LUDWIG A, STANGL V, STANGL K. Proteasome inhibitors: poisons and remedies. Med Res Rev 2008; 28: 309-327. http://dx.doi.org/10.1002/med.20111

[13] MCCONKEY DJ, ZHU K. Mechanisms of proteasome inhibitor action and resistance in cancer. Drug Resist Updat 2008; 11: 164-179. http://dx.doi.org/10.1016/ j.drup.2008.08.002

[14] WU WK, CHO CH, LEE CW, WU K, FAN D, et al. Proteasome inhibition: a new therapeutic strategy to cancer treatment. Cancer Lett 2010; 293: 15-22. http://dx.doi.org/10.1016/ j.canlet.2009.12.002

[15] WILliAMS J, LUCAS PC, GRIFFITH KA, CHOI M, FOGOROS S, et al. Expression of $\mathrm{Bcl}-\mathrm{xL}$ in ovarian carcinoma is associated with chemoresistance and recurrent disease. Gynecol Oncol 2005; 96: 287-295. http://dx.doi.org/10.1016/ j.ygyno.2004.10.026

[16] MICHAUD WA, NICHOLS AC, MROZ EA, FAQUIN WC, CLARK JR, et al. Bcl-2 blocks cisplatin-induced apoptosis and predicts poor outcome following chemoradiation treatment in advanced oropharyngeal squamous cell carcinoma. Clin Cancer Res 2009; 15: 1645-1654. http://dx.doi.org/10.1158/ 1078-0432.CCR-08-2581

[17] SAFAEI R, LARSON BJ, CHENG TC, GIBSON MA, OTANIS, et al. Abnormal lysosomal trafficking and enhanced exosomal export of cisplatin in drug-resistant human ovarian carcinoma cells. Mol Cancer Ther 2005; 4: 1595-1604. http://dx.doi. org/10.1158/1535-7163.MCT-05-0102

[18] SAFAEI R, KATANO K, LARSON BJ, SAMIMI G, HOLZER $A K$, et al. Intracellular localization and trafficking of fluorescein-labeled cisplatin in human ovarian carcinoma cells. Clin Cancer Res 2005; 11: 756-767.

[19] NAKAYAMA K, KANZAKI A, TERADA K, MUTOH M, OGAWA K, et al. Prognostic value of the Cu-transporting ATPase in ovarian carcinoma patients receiving cisplatinbased chemotherapy. Clin Cancer Res 2004; 10: 2804-2811. http://dx.doi.org/10.1158/1078-0432.CCR-03-0454

[20] AIDA T, TAKEBAYASHI Y, SHIMIZU T, OKAMURA C, HIGASIMOTO M, et al. Expression of copper-transporting P-type adenosine triphosphatase (ATP7B) as a prognostic factor in human endometrial carcinoma. Gynecol Oncol 2005; 97: 41-45. http://dx.doi.org/10.1016/j.ygyno.2004.12.042

[21] MOSMANN T. Rapid colorimetric assay for cellular growth and survival: application to proliferation and cytotoxicity assays. J Immunol Methods 1983; 65: 55-63. http://dx.doi. org/10.1016/0022-1759(83)90303-4

[22] BODO J, JAKUBIKOVA J, CHALUPA I, BARTOSOVA Z, HORAKOVA K, et al. Apoptotic effect of ethyl-4-isothiocyanatobutanoate is associated with DNA damage, proteasomal activity and induction of p53 and p21cip1/waf1. Apoptosis 2006; 11: 1299-310. http://dx.doi.org/10.1007/s10495-006$\underline{8760-5}$

[23] BARTKOWIAK D, HOGNER S, BAUST H, NOTHDURFT W, ROTTINGER EM. Comparative analysis of apoptosis in HL60 detected by annexin-V and fluoresceindiacetate. Cytometry 1999; 37: 191-196. http://dx.doi. org/10.1002/(SICI)1097-0320(19991101)37:3<191::AIDCYTO5>3.0.CO;2-U

[24] LI F, SETHI G. Targeting transcription factor NF-kappaB to overcome chemoresistance and radioresistance in cancer therapy. Biochim Biophys Acta 2010; 1805: 167-180.

[25] MELISI D, CHIAO PJ. NF-kappa B as a target for cancer therapy. Expert Opin Ther Targets 2007; 11: 133-144. http:// dx.doi.org/10.1517/14728222.11.2.133

[26] BAUMANN P, MANDL-WEBER S, ODUNCU F, SCHMIDMAIER R. Alkylating agents induce activation of NFkappaB in multiple myeloma cells. Leuk Res 2008; 32: 1144-1147. http://dx.doi.org/10.1016/j.leukres.2007.11.015

[27] GUPTA SC, SUNDARAM C, REUTER S, AGGARWAL BB. Inhibiting NF-kappaB activation by small molecules as a therapeutic strategy. Biochim Biophys Acta 2010; 1799: 775-787.

[28] BAN JO, YUK DY, WOO KS, KIM TM, LEE US, et al. Inhibition of cell growth and induction of apoptosis via inactivation of NF-kappaB by a sulfurcompound isolated from garlic in human colon cancer cells. J Pharmacol Sci 2007; 104: 374-383. http://dx.doi.org/10.1254/jphs.FP0070789

[29] SHEN HM, TERGAONKAR V. NFkappaB signaling in carcinogenesis and as a potential molecular target for cancer therapy. Apoptosis 2009; 14: 348-363. http://dx.doi. org/10.1007/s10495-009-0315-0

[30] LEE CH, JEON YT, KIM SH, SONG YS. NF-kappaB as a potential molecular target for cancer therapy. Biofactors 2007; 29: 19-35. http://dx.doi.org/10.1002/biof.5520290103

[31] DURAJ J, HUNAKOVA L, BODO J, JAKUBIKOVA J, CHOVANCOVA J. Administration of isothiocyanate (E-4IB) and cisplatin leads to altered signalling and lysosomal export in human ovarian carcinoma sensitive- and cisplatin-resistant cells. Neoplasma 2009; 56: 208-214. http://dx.doi.org/10.4149/ neo $2009 \quad 03 \quad 208$

[32] ISHII Y, WAXMAN S, GERMAIN D. Targeting the ubiquitinproteasome pathway in cancer therapy. Anticancer Agents Med Chem 2007; 7: 359-365. http://dx.doi.org/10.2174/ $\underline{187152007780618180}$

[33] BAUD V, DERUDDER E. Control of NF-kappaB activity by proteolysis. Curr Top Microbiol Immunol 2011; 349: 97-114. http://dx.doi.org/10.1007/82 2010 101

[34] TSUKAMOTO S, YOKOSAWA H. Targeting the proteasome pathway. Expert Opin Ther Targets 2009; 13: 605-621. http:// dx.doi.org/10.1517/14728220902866851

[35] CRAWFORD LJ, WALKER B IRVINE AE. Proteasome inhibitors in cancer therapy. J Cell Commun Signal 2011; 5: 101-110. http://dx.doi.org/10.1007/s12079-011-0121-7

[36] CAVO M. Current status of bortezomib in the treatment of multiple myeloma. Curr Hematol Malig Rep 2007; 2: 128-137. http://dx.doi.org/10.1007/s11899-007-0018-y 
[37] KUBICEK GJ, AXELROD RS, MACHTAY M, AHN PH, ANNE PR, et al. Phase I Trial Using the Proteasome Inhibitor Bortezomib and Concurrent Chemoradiotherapy for Headand-Neck Malignancies. Int J Radiat Oncol Biol Phys 2012; 83: 1192-1197. http://dx.doi.org/10.1016/j.ijrobp.2011.09.023

[38] EICHHOLTZ-WIRTH H, SAGAN D. IkappaB/NF-kappaB mediated cisplatin resistance in HeLa cells after low-dose gamma-irradiation is associated with altered SODD expression. Apoptosis 2000; 5: 255-263. http://dx.doi.org/10.1023/ A:1009656513307

[39] SEOL DW. p53-Independent up-regulation of a TRAIL receptor DR5 by proteasome inhibitors: a mechanism for proteasome inhibitor-enhanced TRAIL-induced apoptosis.
Biochem Biophys Res Commun 2011; 416: 222-225. http:// dx.doi.org/10.1016/j.bbrc.2011.11.053

[40] JAIN HV, MEYER-HERMANN M. The molecular basis of synergism between carboplatin and ABT-737 therapy targeting ovarian carcinomas. Cancer Res 2011; 71: 705-715. http://dx.doi.org/10.1158/0008-5472.CAN-10-3174

[41] KROEMER G, GALLUZZI L, BRENNER C. Mitochondrial membrane permeabilization in cell death. Physiol Rev 2007; 87: 99-163. http://dx.doi.org/10.1152/physrev.00013.2006

[42] TAJEDDINE N, GALLUZZI L, KEPP O, HANGEN E, MORSELLI E, et al. Hierarchical involvement of Bak, VDAC1 and Bax in cisplatin-induced cell death. Oncogene 2008; 27: 4221-4232. http://dx.doi.org/10.1038/onc.2008.63 